\title{
Development of professional competence of present and future teachers under the conditions of transformational processes in education
}

Chernysh V. Valentyna ${ }^{1}$

Zadorina Olha ${ }^{2}$

Melnyk Kateryna ${ }^{3}$

Khromova I. Olga ${ }^{4}$

Danyliuk M. Mykola $^{5}$

\section{Journal for Educators, Teachers and Trainers, Vol. 11 (1)}

\author{
https://jett.labosfor.com/
}

Date of reception: 11 March 2020

Date of revision: 11 June 2020

Date of acceptance: 11 August 2020

Chernysh V. Valentyna, Zadorina Olha, Melnyk Kateryna, Khromova I. Olga, Danyliuk M. Mykola. (2020). Development of professional competence of present and future teachers under the conditions of transformational processes in education. Journal for Educators, Teachers and Trainers, Vol. 11(1). 56-67.

${ }^{1}$ Doctor Hab. of Pedagogical Sciences (EdD), Professor, Head of Department of Foreign Languages Methodology Teaching and Information and Communication Technologies, Kyiv National Linguistic University, Faculty of Roman Philology and Translation, Department of Foreign Languages Methodology Teaching and Information and Communication Technologies, ORCID identifier: 0000-0002-5457-5024

${ }^{2}$ Candidate of Pedagogical Sciences, Senior Lecturer of the Department of Teaching Methods and Content of Education, Municipal Institution of Higher Education "Odessa Academy of Continuous Education of Odessa Regional Council", Department of Teaching Methods and Content of Education

${ }^{3}$ Assistant of the Department, Vinnytsia State Mykhailo Kotsiubynskyi State Pedagogical University, foreign language faculty, English Philology Department, ORCID identifier: 0000-0001-9819-58277

${ }^{4}$ Candidate of Philosophical Sciences, Associate Professor, State University of Infrastructure and Technologies, Faculty of Railway Transport Management, Department of Philosophy and History of Science and Technology, ORCID identifier: 0000-0002-5445-4230

${ }^{5}$ Ph.D. in Pedagogy, Associate Professor, H. S. Skovoroda Kharkiv National Pedagogical University, Department of Theoretical Musical and Artistic Training, ORCID identifier: 0000-0002-6322-7080 


\title{
https://jett.labosfor.com/
}

\section{Development of professional competence of present and future teachers under the conditions of transformational processes in education} Chernysh V. Valentyna ${ }^{1}$, Zadorina Olha ${ }^{2}$, Melnyk Kateryna ${ }^{3}$, Khromova I. Olga ${ }^{4}$, Danyliuk M. Mykola ${ }^{5}$ ${ }^{1}$ Doctor Hab. of Pedagogical Sciences (EdD), Professor, Head of Department of Foreign Languages Methodology Teaching and Information and Communication Technologies, Kyiv National Linguistic University, Faculty of Roman Philology and Translation, Department of Foreign Languages Methodology Teaching and Information and Communication Technologies, ORCID identifier: 0000-0002-5457-5024

${ }^{2}$ Candidate of Pedagogical Sciences, Senior Lecturer of the Department of Teaching Methods and Content of Education, Municipal Institution of Higher Education "Odessa Academy of Continuous Education of Odessa Regional Council", Department of Teaching Methods and Content of Education

${ }^{3}$ Assistant of the Department, Vinnytsia State Mykhailo Kotsiubynskyi State Pedagogical University, foreign language faculty, English Philology Department, ORCID identifier: 0000-0001-9819-58277

${ }^{4}$ Candidate of Philosophical Sciences, Associate Professor, State University of Infrastructure and Technologies, Faculty of Railway Transport Management, Department of Philosophy and History of Science and Technology, ORCID identifier: 0000-0002-5445-4230

5 Ph.D. in Pedagogy, Associate Professor, H. S. Skovoroda Kharkiv National Pedagogical University, Department of Theoretical Musical and Artistic Training, ORCID identifier: 0000-0002-6322-7080

\begin{abstract}
Currently, the modern education system is in the process of transformation processes. One of the directions of reforming the education system in Ukraine should be directed at improving the level of professional competence of teachers, their knowledge, skills and abilities. The purpose of the academic paper is to study approaches to the formation of professional competence of present and future teachers under the conditions of transformational processes in education. The following scientific methods have been used in the academic paper, namely: methods of theoretical analysis and description - in order to reveal the theoretical and methodological aspects of the development of teachers' professional competence in the conditions of transformational processes in education; methods of grouping, comparison and synthesis - to consider the features of the development of professional competence of teachers in Canada and Ukraine. In Canada, the development of professional competence of modern teachers involves the preparation of an exam by educators, which would certify the high level of their effectiveness. Intercultural competence-based teaching methods, introduced at higher educational institutions in Canada, have a positive effect on the formation of professional competences of future teachers. In Ukraine, the key directions for improving the level of professional competence of both present and future teachers should be professional selfimprovement, which is achieved through purposeful self-educational activity. The professional activity of a teacher should include love for children, pedagogical foresight, knowledge of the subject of activity, pedagogical tact, innovative scientific and pedagogical thinking. The development of professional competence is a dynamic process of assimilation and modernization of professional experience, which leads to the development of individual professional qualities, the accumulation of professional experience, which involves continuous development and self-improvement. The professional competence of teachers allows not only applying basic knowledge and skills, but it also forms the ability to carry out practical activities in specific professional situations; it provides creative
\end{abstract}


solutions to professional problems and makes it possible to easily navigate in a professional environment and possess a culture of work. The formation of teachers' professional competence should be carried out on the basis of the general provisions of the system approach and the use of other scientifically sound approaches.

Keywords: professional self-improvement, self-educational activity, the program of development of professional competence, pedagogical tact, innovativeness of scientific and pedagogical thinking.

\section{INTRODUCTION}

The National Strategy of the Development of Education in Ukraine for the period up to 2021 states that the renewal of its goals and content, modernization of the structure and organization should be carried out on the basis of a competence-based approach. The construction of a new type of education involves the transition of all basic educational standards from the language of knowledge to the language of competence requirements, which, first of all, means a qualitatively different nature of educational outcomes. According to this provision, higher educational institutions have a task to restructure their activities and transfer them to a competence-based basis. The vector of professionalism in this case should be focused not on knowledge, but on activity (application of knowledge to take active action), that is, professional competence. The level of professional competence of specialists in any field, including modern teachers, to a great extent depends on the effectiveness of the educational process in higher educational institutions. Solution of the problem of training a new generation of pedagogical qualified personnel on the basis of a competence-based approach in the context of the educational component of the Lisbon Strategy of the Development of Education and Professional Teachers' Training requires technological variability in ensuring innovative processes.

The system of education in the context of ensuring the professionalism and qualifications of modern teachers is guided by a competence-based approach. Along with this, modern pedagogical experience indicates that the knowledge, skills and abilities of teachers are currently an important element in the formation of professional competence of teachers, especially today, when there are significant transformational processes in education.

\section{LITERATURE REVIEW}

Studying the competences of teachers in Canada, Korpan C., Sheffield S. Le-May and Verwoord R. (2015) note that "the stages of development for a framework of teaching assistant (TA) competencies initiated by the Teaching Assistant and Graduate Student Advancement (TAGSA) special interest group (SIG) of the Society of Teaching and Learning in Higher Education (STLHE)" (Korpan, C., Sheffield, S. Le-May, Verwoord, R., 2015). Goodman G., Arbona C. and Dominguez de Rameriz R. (2008) emphasize that currently more and more countries in the world require teachers to take an exam that would demonstrate a high level of efficiency of their activities, while applying minimal competences (G., Arbona, C., Dominguez de Rameriz, R., 2008).

At the same time, Guay F., Roy A. and Valois P. (2017) in the scientific work "Teacher structure as a predictor of students' perceived competence and autonomous motivation: The moderating role of differentiated instruction" note that through their own competences the teacher to some extent positively affects the formation of students' autonomy. However, such a positive influence of the teacher on students is observed only when the teacher uses differentiated learning strategies, and the teacher's competence is acceptable. Herewith, the negative impact on the formation of students' autonomy takes place when teachers provide untimely differentiated instructions for learning (Guay, F., Roy, A., Valois P., 2017).

LeGros N. and Faez F. (2012) note that the formation of professional competences of students - future teachers is positively influenced by intercultural competence-based teaching methods (LeGros, N., Faez, F., 2012).

Tait M. (2008) in his investigation "Resilience as a Contributor to Novice Teacher Success, Commitment, and Retention" emphasizes that the development of teachers' professional competences is influenced by such character traits as resilience, personal effectiveness, and emotional intelligence (Tait, M., 2008).

Wawan W. (2016) in the scientific work "The Relationship between Teacher Competence, Emotional Intelligence and Teacher Performance Madrasah Tsanawiyah at the District of Serang Banten" considers the features of the interconnection between competence, emotional intelligence and a teacher's performance. According to the results of the study, the scientist has come to conclusion that the level of efficiency of the 
teacher increases by improving the level of his professional competence and emotional intelligence (Wawan, W., 2016).

Petrikova N. I. notes that the professional competence of teachers is formed by: intellectual, psychological, managerial, motivational, project and methodological competence. The teacher should also have a high level of social responsibility, strive for self-education, develop spiritually, be intelligent, be optimistic about the tasks set before him, think critically and creatively (Petrikova, N. I.).

According to viewpoint of Chukhraj I. B. (2017), the components of a teacher's professional competence are as follows: informational, productive, subject, multicultural, social, psychological, mathematical, moral, autonomous competence, as well as the personal qualities of the teacher.

Slipenko V. (2019) notes that the key competences of a teacher that need to be developed are motivationalpersonal, general pedagogical and special-subject, culturological and analytical-prognostic competences.

According to the investigation's results of Shevchenko, L. S., Kryzhanovskyi, A. I. (2018), reflected in the "Experimental verification of the efficiency of the formation of trainee teachers' professional competence with the use of web technologies", the key factors influencing the development of professional competence of teachers are internal factors, namely: motivation, activity, emotions, will, as well as external factors: the content of educational material, technologies, methods, tools and forms.

In turn, Beskorsa O. (2018), studying the basic principles of professional competence of teachers in the context of open education, notes that the professional and pedagogical competence of teachers under modern conditions should be considered as an integral characteristic of the personality.

Maiier, N., Ustymenko, O. (2018) in the scientific article "Modern methods and technologies for developing pre-service foreign language and culture teachers' methodological competence" identify a number of indicators that characterize the professional competence of teachers, namely: the total amount of knowledge, skills and abilities; ability to apply their own knowledge and skills in practical activities; ability to determine the potential consequences of actions; results of professional activity; level of practical experience; flexibility of training methods used by the teacher; level of critical thinking; professional abilities and individual psychological qualities. Danylenko, O. (2018) highlights the conditions that affect the process of developing professional competence of teachers. These include the development of motivation of students - future teachers in the context of further pedagogical activities, a favorable and positive attitude of a potential teacher to the process of acquiring knowledge that in the future will need to be represented to pupils, organization of training of students - future teachers with the use of activity approach, organization of educational process on formation of teachers' professional abilities and creative skills in the future.

Yaburova, O. (2019) exploring the issue of motivation at school, points out that the key structural and functional component of speech development of primary school pupils with dysgraphia is the motivation of teachers, which forms a positive attitude of pupils to learning.

The problem of professional competence of teachers is widely reflected in scientific publications. Nevertheless, the issue of its improvement remains open for further research in the context of educational reform, the emergence of new concepts and author's programs of professional competence of teachers, strengthening public demand for highly qualified specialists. The importance of taking into account the Canadian experience in the process of improving the professional competence of teachers in Ukraine is also the basis for further research in this direction.

\section{The purpose of the research}

The purpose of the scientific article is to study approaches to the formation of professional competence of present and future teachers under the conditions of transformational processes in education.

In order to achieve the goal in the scientific article, the following research objectives have been set:

- to reveal approaches to the formation of professional competence of teachers in the conditions of transformation processes in education;

- to consider the features of the development of professional competence of teachers in Canada;

- to study the key aspects of the formation and development of professional competence of teachers in the conditions of transformation processes in education in Ukraine.

\section{METHODS (MATERIALS AND METHODS OF THE RESEARCH)}


Achieving the goal and research objectives requires the application of a number of scientific methods, among which the following ones have been used in the scientific article, namely: methods of theoretical analysis and description - to reveal the theoretical and methodological aspects of professional competence of teachers under the conditions of transformational processes in education; methods of grouping, comparison and synthesis - to consider the features of the development of professional competence of teachers in Canada and to study key aspects of the formation and development of professional competence of teachers in the context of transformational processes in education in Ukraine.

The methodological basis of the scientific article is based on the curricula of a number of institutions that regulate the education system in countries and higher educational institutions of Canada and Ukraine concerning ensuring the development of professional competence of teachers under the conditions of the transformation processes in education. The objects of the study are higher educational institutions in Canada (British Columbia), which provide specialized training for teachers in the context of the development of their professional competences, namely: Simon Fraser University, Trinity Western University, Thompson Rivers University, University of the Fraser Valley, University of British Columbia, University of Northern British Columbia, University of Victoria, University of British Columbia - Okanagan, Vancouver Island University, National Center on Education and the Economy. In Ukraine, the objects of research are educational institutions that have developed their own concepts and author's programs of teachers' pedagogical competence, namely: Khmelnytsky Humanitarian and Pedagogical Academy, Institute of Postgraduate Education of Kyiv University named by Borys Hrynchenko, Sumy Regional Institute of Postgraduate Pedagogical Education.

\section{RESULTS}

In the process of revealing the theoretical and methodological aspects of the development of professional competence of teachers under the conditions of transformation processes in education, a number of features of this process in Canada and Ukraine have been identified. In our viewpoint, the combination of scientific achievements and pedagogical experience of Ukraine and Canada will guarantee the solution of numerous existing problems in modern domestic education.

Comparative description of pedagogical education in Ukraine and Canada has been reflected in Table 1.

Table 1: Comparative description of pedagogical education in Ukraine and Canada

\begin{tabular}{|l|l|l|}
\hline $\begin{array}{l}\text { Features of the structure and } \\
\text { content of pedagogical education }\end{array}$ & Canada & Ukraine \\
\hline $\begin{array}{l}\text { Educational programs } \\
\text { Curricula) }\end{array}$ & $\begin{array}{l}\text { Dependence on the choice of province, } \\
\text { university, teacher; multivariate } \\
\text { educational standards. }\end{array}$ & $\begin{array}{l}\text { Compliance of programs' } \\
\text { components with national } \\
\text { educational standards. }\end{array}$ \\
\hline $\begin{array}{l}\text { The connection between theory } \\
\text { and practice }\end{array}$ & $\begin{array}{l}\text { The tendency for the organic } \\
\text { connection of theory and practice in } \\
\text { almost every topic. }\end{array}$ & $\begin{array}{l}\text { The existence of a certain gap } \\
\text { between theory and practice, which } \\
\text { are separated from each other. }\end{array}$ \\
\hline $\begin{array}{l}\text { The nature of knowledge } \\
\text { acquisition }\end{array}$ & $\begin{array}{l}\text { Mostly creative and debatable, focused } \\
\text { on the student's position. } \\
\text { Implementation of a personal-activity } \\
\text { approach using a variety of active } \\
\text { creative teaching methods. }\end{array}$ & $\begin{array}{l}\text { Mostly academic-affirming, } \\
\text { teacher-oriented. Application of } \\
\text { mainly theoretical methods, the } \\
\text { main of which is a lecture. }\end{array}$ \\
\hline $\begin{array}{l}\text { The nature of the organization of } \\
\text { pedagogical practice }\end{array}$ & $\begin{array}{l}\text { It clearly planned and controlled by } \\
\text { the school and university } \\
\text { administration; pedagogical practice is } \\
\text { comprehensive and has certain } \\
\text { evaluation criteria. Recently, the } \\
\text { organization of pedagogical practice } \\
\text { has begun to be modernized with } \\
\text { application of new information } \\
\text { technologies. }\end{array}$ & $\begin{array}{l}\text { The practice is quite clearly planned } \\
\text { and controlled by the school } \\
\text { administration; however, in the } \\
\text { process of pedagogical practice the } \\
\text { individualization of the formation of } \\
\text { professional and pedagogical skills } \\
\text { of students is not sufficiently carried } \\
\text { out. }\end{array}$ \\
\hline Eritical analysis of educational
\end{tabular} \mid \begin{tabular}{l} 
The educational process is aimed \\
\hline
\end{tabular}




\begin{tabular}{|c|c|c|}
\hline material & $\begin{array}{l}\text { assessment of any concepts, on } \\
\text { developing one's own position. }\end{array}$ & $\begin{array}{l}\text { more at mastering this material and } \\
\text { is not sufficiently focused on the } \\
\text { analytical approach, the } \\
\text { development of critical thinking of } \\
\text { students. }\end{array}$ \\
\hline Teacher - student interaction style & $\begin{array}{l}\text { Democratic style that forms } \\
\text { partnerships. }\end{array}$ & $\begin{array}{l}\text { In most cases authoritarian style, in } \\
\text { which the teacher plays the leading } \\
\text { role. }\end{array}$ \\
\hline Content of educational programs & $\begin{array}{l}\text { Curricula are developed taking into } \\
\text { account modern world tendencies for } \\
\text { equipping students with deep } \\
\text { knowledge. The curricula have a large } \\
\text { selection of subjects that have a great } \\
\text { practical orientation. }\end{array}$ & $\begin{array}{l}\text { There is not much variety in } \\
\text { curricula. In most cases these are } \\
\text { theoretical courses that provide } \\
\text { thorough subject knowledge. }\end{array}$ \\
\hline $\begin{array}{l}\text { Equipping students with research } \\
\text { methods }\end{array}$ & $\begin{array}{l}\text { It is carried out during the study of } \\
\text { most educational topics by performing } \\
\text { specific tasks. }\end{array}$ & $\begin{array}{l}\text { Sometimes it is considered as a } \\
\text { separate topic or section of the } \\
\text { program and is of an introductory } \\
\text { nature. }\end{array}$ \\
\hline Theory of pedagogy & $\begin{array}{l}\text { It is studied not as an independent } \\
\text { discipline, but only as its separate } \\
\text { elements. Pedagogical problems are } \\
\text { considered mainly in a psychological } \\
\text { context. }\end{array}$ & $\begin{array}{l}\text { Pedagogy is studied as a separate } \\
\text { independent discipline. Pedagogy } \\
\text { and psychology are studied in } \\
\text { parallel. }\end{array}$ \\
\hline Organization of independent work & $\begin{array}{l}\text { Independent work is of great } \\
\text { importance in the process of the } \\
\text { student's training. }\end{array}$ & $\begin{array}{l}\text { The student works very little } \\
\text { independently. As a rule, his task is } \\
\text { to study what the teacher said. }\end{array}$ \\
\hline
\end{tabular}

Source: Compiled by author

Based on the study of the essence and content of modern approaches to the issue of improving the pedagogical skills of teachers in the system of higher pedagogical education in Canada, we have come to conclusion that the teacher's skills are formed through multilevel organization of the educational process, including general education, psychological and pedagogical training.

The specialized educational institutions of Canada, conducting training of teachers, use a number of curricula that determine the standards for the preparation and formation of the qualifications of students - future teachers. The initial level of the teacher's education involves obtaining a bachelor's degree, and in some cases a bachelor's degree with additional certification of education, which makes it possible to obtain the additional level of qualification required for teaching subjects at secondary school. In some Canadian provinces, teachers are required to take an examination to obtain a certificate attesting to their qualifications (National Center on Education and the Economy, 2020).

In addition, according to the National Center on Education and the Economy, there are about 50 curricula in Canada, according to which students are trained in order to obtain a teacher's specialty (National Center on Education and the Economy, 2020).

The professional development of teachers in Canada is based on the content of knowledge, focus on results (Campbell, C., Osmond-Johnson, P., Faubert, B., Zeichner, K., Hobbs-Johnson, A. (with Brown, S., DaCosta, P., Hales, A., Kuehn, L., Sohn, J., \& Steffensen, K.), 2017).

In Canada, the level of teachers' salaries is determined by each province. The average salary of a teacher who has just come to teach at a school is 39179,00 USD (according to data as of 2015). In the north-western provinces of Canada, the average wage is 59 401, 00 USD, and teachers who work the first year - 45 555, 00 USD. At the same time, in order to achieve the maximum level of remuneration, a teacher must work for 15 years (National Center on Education and the Economy, 2020). 
As for the features of professional development of teachers in Canada, as shown in Figure 1, each of the provinces (for example, New Brunswick, Alberta, British Columbia, Ontario, Pan-Canadian) has its own requirements for this process.

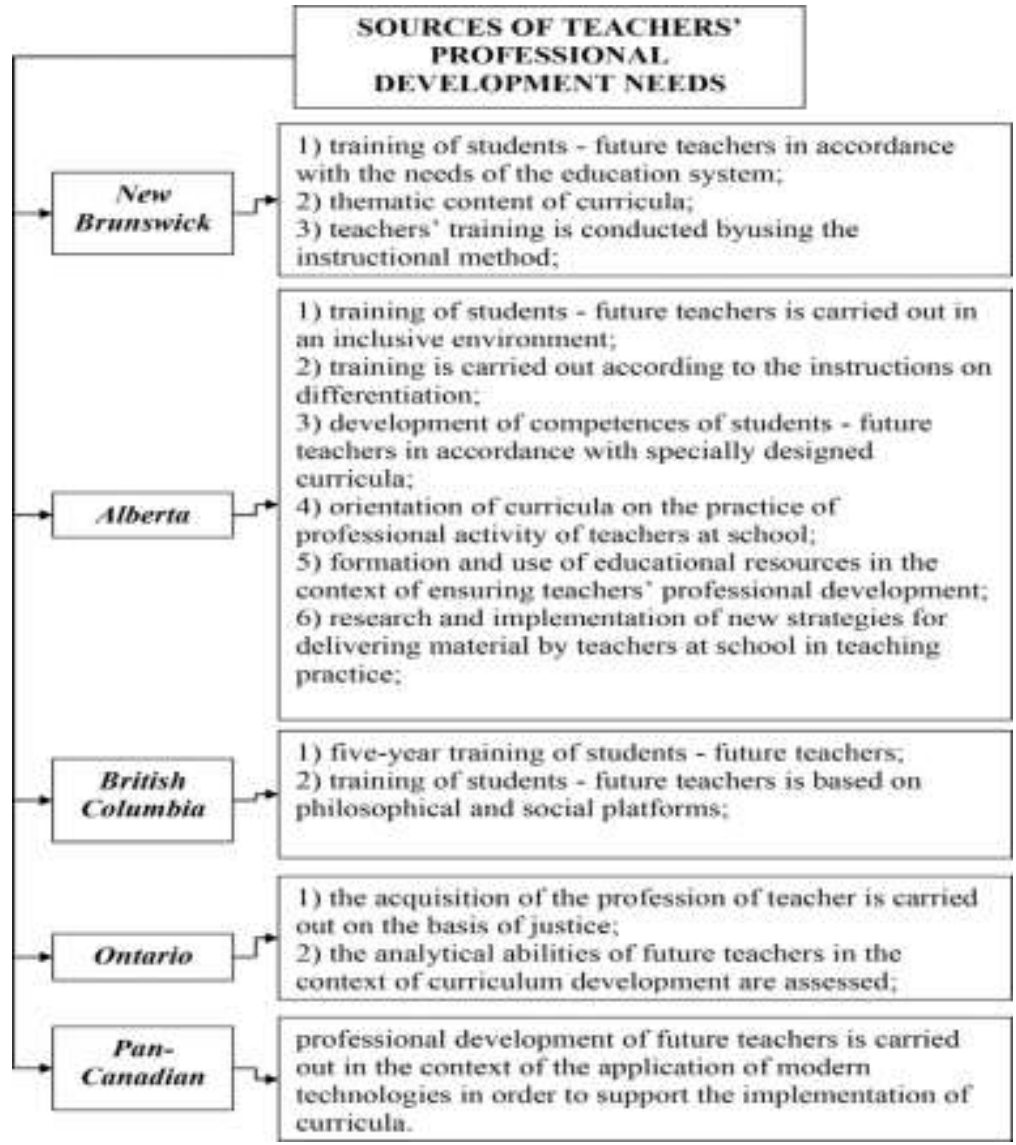

Source: Compiled by the authors by (Campbell, C., 2017)

Figure 1: Features of teachers' professional development in some provinces of Canada

For instance, in British Columbia, the province of Canada, vocational training of teachers in the context of ensuring the development of their professional competences is provided by such institutions of tertiary education in this region, as: (British Columbia, 2020): Simon Fraser University, Trinity Western University, Thompson Rivers University, University of the Fraser Valley, University of British Columbia, University of Northern British Columbia, University of Victoria, University of British Columbia - Okanagan, Vancouver Island University, National Center on Education and the Economy.

In Ukraine, curricula for the development of professional competence of teachers are offered by the following educational institutions: Khmelnytsky Humanitarian and Pedagogical Academy, Institute of Postgraduate Education of Kyiv University named by Borys Hrynchenko, Sumy Regional Institute of Postgraduate Pedagogical Education.

According to Article 1 of the Law of Ukraine "On Higher Education", the term "competence" should be understood as "the ability of a person to successfully socialize, learn, carry out professional activities, which arises on the basis of a dynamic combination of knowledge, skills, ways of thinking, attitudes, values, other personal qualities" (Verkhovna Rada of Ukraine).

In Ukraine, the professional competence of teachers is formed by intellectual, psychological, managerial, motivational, project, informational, productive, subject, multicultural, social, mathematical (analytical), moral, methodological, communicative, legal and autonomous competences. The profession of a teacher involves love for children, knowledge of the subject, pedagogical tact, innovative scientific and pedagogical thinking.

The Ministry of Education and Science of Ukraine has identified the improvement of the level of professional competence of teachers (in the context of transformation processes in education) as one of the areas of reforming the education system in Ukraine (Monastery of educational and science in Ukraine). 
In the course of the study it has been found that in order to increase the level of professional competence of teachers it is necessary:

- to form a proper methodological environment and achieve positive relationships with others, in particular with colleagues;

- to create a flexible system of direct teacher's education, based on an individual approach, self-educational activities and targeted systematic activities of the teacher on the methodological topic, self-education, as well as reflection on his own activities;

- to create an educational and information space, access to resources of which should be equal for all teachers;

- to ensure readiness for innovative activities of teachers, while giving priority to educational technologies

(Blyznyuk, T. (2017).

For instance, the basic principles of the process of developing the professional competence of teachers of Ukrainian language and literature are as follows:

- ensuring the systematic study of scientific philological, linguistic, psychological, pedagogical and political literature;

- participation in school, interschool and district methodological associations, conferences, seminars,

pedagogical readings;

- improvement of educational work;

- conducting research in the field of philology;

- presentation of reports, including in the media;

- author's publishing activity.

It should be noted that the algorithm for the development of professional competence of teachers under the conditions of transformation processes in education in Ukraine includes several stages, the detailed characteristics of which are presented in Figure 2.

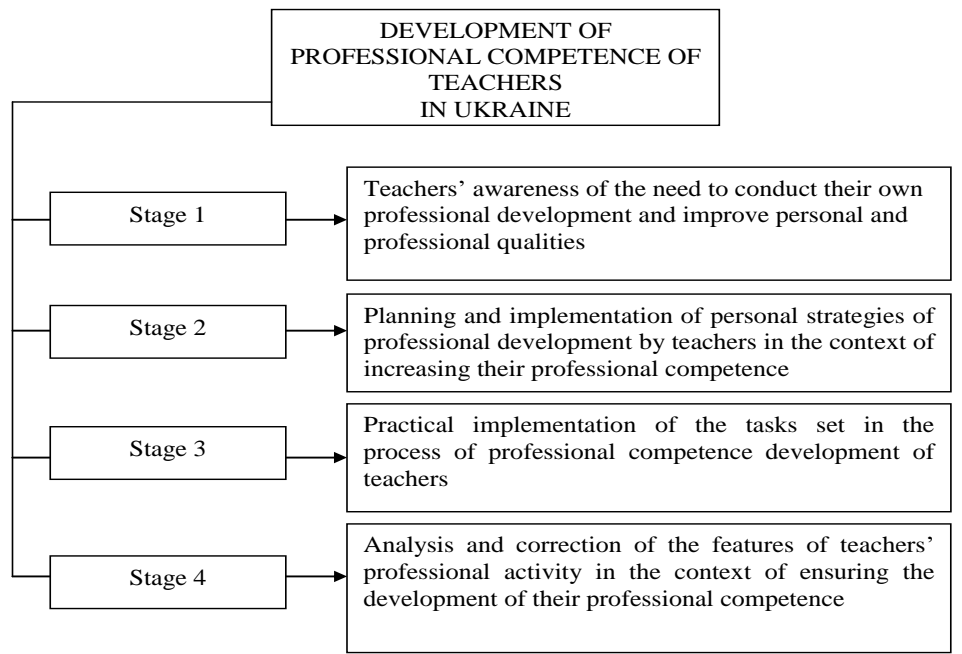

Source: Compiled by the authors by Byrka, M. F., Sushchenko, A. V., Lukashiv, T.O., 2019

Figure 2: Stages of development of professional competence of teachers in Ukraine

The process of developing the professional competence of a teacher (on the example of a teacher of Ukrainian language and literature) in Ukraine is based on such principles as (Balashova, S., Holovko, N., 2019):

- $\quad$ the principle of andragogy (based on education of adults);

- $\quad$ the principle of continuity (based on the education that the teacher receives throughout life);

- $\quad$ the principle of interconnection of theory and practice (based on the acquisition of practical skills and abilities on the basis of acquired theoretical knowledge);

- $\quad$ the principle of mobility (characterizes the correspondence of the features of self-education to the level of professional competence of the teacher);

- $\quad$ the principle of integration (characterizes the integration of the teacher's competences);

- $\quad$ the principle of processability (reflects the features of innovative technologies in education); 
- $\quad$ the principle of activity and interactivity (characterizes the activity and dialogical feature of the educational process);

- $\quad$ the principle of individualization (reflects the features of the individual educational space);

- $\quad$ the principle of self-organization (shows the teacher's ability to rationally and thoughtfully organize

professional activities);

- $\quad$ the principle of integrity (characterizes the system of self-educational activities);

- $\quad$ - the principle of reflectivity (demonstrates the features of assessing the professional activities of teachers,

which are aimed at drawing conclusions);

- $\quad$ the principle of system and sequence (reflects the logical semantic interconnection);

- $\quad$ - the principle of self-implementation (characterizes the peculiarities of the teacher's own capabilities and abilities);

- $\quad$ the principle of analyticity (reflects the features of monitoring and correction of information by the teacher).

Higher educational institutions, specializing in providing postgraduate pedagogical education services, are also involved in ensuring the development of teachers' professional competence.

For instance, the Sumy Regional Institute of Postgraduate Pedagogical Education has introduced a course for the development of professional competence of teachers, which is based on corporate training and the author's program of this institute. In the context of undergoing this course, the teacher takes an active part in various business games, master classes. This, in turn, is an important component of the latest forms of education, the results of which are the development of the teacher's competence (Sumy Regional Institute of Postgraduate Pedagogical Education).

The Khmelnytsky Humanitarian and Pedagogical Academy has presented the Concept of pedagogical competence of teachers in the system of degree training of specialists of primary education. According to the investigations of the authors of this concept (Banashko L. V., Sevastjjanovoji O. M., Kryshhuka B. S. \& Tafincevoji S. I), professional competence of a teacher is a basic characteristic of a teacher's activity as a specialist, the main components of which are content (that is, knowledge) and procedurality (that is, ability). In addition, the key features of a teacher's professional competence are as follows: mobility of knowledge; flexibility of methods of professional activity; high level of critical thinking (Khmelnytsky Humanitarian and Pedagogical Academy).

Along with this, the Institute of Postgraduate Education of the Borys Hrinchenko University of Kyiv has developed a program for the development of professional competence of teachers, which provides more than 300 training modules in order to improve professional, communicative, cultural, information-digital, legal, social-civic, financial and psychological-pedagogical competence of teachers (Institute of Postgraduate Education of Kyiv University named by Borys Hrynchenko).

\section{DISCUSSION}

The understanding of the concept of professional competences in Ukraine and Canada is formed with an orientation towards the established norms and procedures that have historically developed in the education system of each of the countries and university traditions, taking into account the level of education development. When considering the professional competences of teachers in Canada, it is important to note that their professional training, qualifications and practical activities are of paramount importance. Professional training of a teacher includes mental abilities, a subject of specialization at a university, the presence of professional experience, etc., and practical activity consists in the ability to represent the educational material in a quality manner, formulate learning goals, choose the right tools for assessing knowledge, use innovative methods and forms of organizing the educational process etc.

The investigations (LeGros, N., Faez, F., 2012) prove that the formation of professional competences of future teachers is positively influenced by intercultural competence-based teaching methods, which are introduced in higher educational institutions of Canada.

The researches of Tait M. (2008) in the context of professional competences of teachers make it possible to identify certain character traits that affect the development of professional competences. These include resilience, personal effectiveness and emotional intelligence. The key assessing indicators of teachers' resilience are as follows: the ability to positively influence the situation, good adaptation to unexpected environmental 
influences, flexibility, speed of response to change, the ability to maintain relationships with others, the ability to solve problems, persistence, optimism, ability to handle risks and eliminate them. At the same time, the personal effectiveness of the teacher is considered through the willingness to apply different teaching methods, to support and help when there is a significant need, through self-control, focus on solving complex problems. The teacher's emotional intelligence is characterized by stress resistance, initiative and self-regulation (Tait, M., 2008).

In Ukraine, the professional competence of teachers is formed by such competences, as: intellectual competence, psychological competence, managerial competence, motivational competence, project competence, information competence, productive competence, subject competence, multicultural competence, social competence, mathematical (analytical) competence, moral competence, methodological competence, communicative competence, legal competence and autonomous-based competence.

The teacher's mastery of information competence reflects the teacher's ability to possess information technology, which is necessary for the processing and use of information. The productive competence of the teacher reflects his ability to work, while obtaining the proper result of work. Subject competence reflects the knowledge, skills and abilities of a teacher in relation to a particular subject or specialty. Multicultural competence characterizes the level of mastery of culture by the teacher and his ability to understand others. A key feature of a teacher's social competence is to avoid conflict situations. The peculiarity of psychological competence is the teacher's ability to use his own knowledge, skills and abilities in order to organize relationships in the educational process. Analytical competence of the teacher involves the ability to work with numerical data, while possessing mathematical abilities. The essence of moral competence is the readiness and ability of the teacher to adhere to moral principles. Autonomous-based competence characterizes the teacher's ability to self-development, creativity, self-education, self-determination (Chukhraj I. B. (2017).

When considering the development of professional competence of teachers in the context of open education, it is important to note that the professional and pedagogical competence of teachers should be considered as an integral characteristic of personality, including a comprehensive combination of thorough, systematic, multifunctional knowledge, professional and pedagogical value orientations, acmeological invariants, in particular special pedagogical abilities, properties, personal qualities (temperament, intelligence, inclinations, beliefs, needs, guidelines), etc., acmeological professional position. They provide the professional development of the teacher through formal, nonformal, informal education, readiness to carry out innovative highly productive professional and pedagogical activity in modern social-cultural conditions.

In order to increase the level of professional competence of a teacher it is necessary: to form a proper methodological environment and achieve positive relationships with others, in particular with colleagues; to build a flexible system of direct education of the teacher, based on an individual approach to the teacher, selfeducational activities of the teacher, targeted systematic activities of the teacher on the methodological topic, self-education, as well as reflection on his own activities; to create an educational and information space, access to resources, which should be equal for all teachers; to ensure readiness for innovative activity of teachers, giving priority to educational technologies.

In Ukraine, the curricula of specialized higher educational institutions, providing the development of professional competence of teachers, offer a number of courses and specially developed concepts based on corporate learning and author's programs (for instance, one curriculum may contain an average of 300 training modules related to the development of professional competence of teachers).

Thus, the status of a teacher is radically changing under the conditions of education reform; accordingly, the requirements for his professional competences increase. The formation of professional competences is a process that requires a teacher to constantly improve, acquire new knowledge and skills, professional development. The professional competence of a teacher depends on his personal characteristics, the main sources of which are learning and experience.

\section{CONCLUSION}

The development of professional competence of teachers is carried out in accordance with specially designed curricula.

In Canada, the training, qualifications and practical activities of teachers are of paramount importance, taking into account personal qualities and character traits that influence the development of professional competences 
(including resilience, personal effectiveness and emotional intelligence). In Ukraine, the basic professional competences of teachers include: informational, productive, subject, moral, analytical, intellectual, managerial, motivational and other competences. The main direction of improving the level of professional competence is professional self-improvement through purposeful self-educational activities.

The practical significance of the present study lies in the fact that the use of the best Ukrainian and Canadian experience will help increase the professional competences of current and future teachers.

The development of professional competence is a dynamic process of assimilation and modernization of professional experience, which leads to the development of individual professional qualities, the accumulation of professional experience, involving continuous development and self-improvement. Professional competence of teachers allows not only applying their knowledge and skills, but also forming the ability to practice in specific professional situations, creative solution of professional problems, and makes it possible to easily navigate in a professional environment and have a culture of work. The formation of professional competence of teachers should be carried out on the basis of the general provisions of the system approach and the use of other scientifically sound approaches.

Prospects for further research in this direction involve an in-depth study of modern approaches to the formation of professional competence of teachers in educational institutions of Ukraine and international experience of educational activities.

\section{REFERENCES}

1. Bachelor of education. University of British Columbia - Okanagan. URL: https://education.ok.ubc.ca/degrees-programs/bachelor-of-education/ (date of issue 02.06.2020).

2. Bachelor of education program. University of British Columbia. URL: https:/ / teach.educ.ubc.ca/bachelor-of-education-program/ (date of issue 02.06.2020).

3. Campbell, C. (2017). Developing Teachers' Professional Learning: Canadian Evidence and Experiences in a World of Educational Improvement. Canadian Journal of Education, 40 (2), 1-33.

4. Campbell, C., Osmond-Johnson, P., Faubert, B., Zeichner, K., Hobbs-Johnson, A. (with Brown, S., DaCosta, P., Hales, A., Kuehn, L., Sohn, J., \& Steffensen, K.). (2017). The state of educators' professional learning in Canada: Final research report. Oxford, OH: Learning Forward. 99. URL: https://www.researchgate.net/publication/325483416_The_State_of_Educators'_Professional_L earning_in_Canada/link/5b10a3a20f7e9b4981007913/download (date of issue 02.06.2020).

5. Canada: Teacher and Principal Quality. National Center on Education and the Economy. URL: http://ncee.org/what-we-do/center-on-international-education-benchmarking/topperforming-countries/canada-overview/canada-teacher-and-principal-quality/ (date of issue 02.06.2020).

6. Chukhraj, I. B. (2017). Rozvytok profesijnoji kompetentnosti vchytelja. Tavrijsjkyj visnyk osvity, 1 (57), 89-94.

7. Education

Trinity

Western

University.

URL: https://www2.gov.bc.ca/gov/content/education-training/k-12/teach/training-andprofessional-development/teacher-education-programs (date of issue 02.06.2020).

8. Goodman, G., Arbona, C., Dominguez de Rameriz, R. (2008). High-Stakes, MinimumCompetency Exams: How Competent Are They for Evaluating Teacher Competence? Journal of Teacher Education, 1. URL: https://doi.org/10.1177/0022487107309972 (date of issue 02.06.2020).

9. Guay, F., Roy, A., Valois, P. (2017). Teacher structure as a predictor of students' perceived competence and autonomous motivation: The moderating role of differentiated instruction. British Journal of Educational Psychology, 87 (2), 224-240. URL: https://doi.org/10.1111/bjep.12146 (date of issue 02.06.2020).

10. Help shape the next generation. University of the Fraser Valley. URL: https://www.ufv.ca/programs/teacher-education/ (date of issue 02.06.2020).

11. Initial Teacher Education Programs. Vancouver Island University. URL: https://education.viu.ca/initial-teacher-education-programs (date of issue 02.06.2020).

12. Koncepcija pedaghoghichnoji kompetentnosti majbutnikh uchyteliv u systemi stupenevoji pidghotovky specialistiv pochatkovoji lanky osvity. Khmeljnycjka ghumanitarno- 
pedaghoghichna akademija. URL: http://www.kgpa.km.ua/?q=node/233 (date of issue 02.06.2020).

13. Korpan, C., Sheffield, S. Le-May, Verwoord, R. (2015). Teaching Assistant Competencies in Canada: Building a Framework for Practice Together. Collected Essays on Learning and Teaching, 8, 219-230.

14. Kovalenko, L. V. (2017). Rozvytok profesijnoji kompetentnosti vchytelja ukrajinsjkoji movy ta literatury v systemi pisljadyplomnoji osvity: metodychnyj posibnyk. Sumy: Niko, 116.

15. Kryvonos, O. B. (2016). Umovy formuvannja profesijnykh kompetentnostej majbutnikh pedaghoghiv. Visnyk Cherkasjkogho universytetu. Serija «pedaghoghichni nauky», 9, 117-122.

16. LeGros, N., Faez, F. (2012). The Intersection Between Intercultural Competence and Teaching Behaviors: A Case of International Teaching Assistants. Journal on Excellence in College Teaching, 23 (3), 7-31.

17. Ministerstvo osvity i nauky Ukrajiny. URL: https://mon.gov.ua/ (date of issue 02.06.2020).

18. Petrikova, N. I. Profesijna kompetentnistj uchytelja - vazhlyva skladova jakisnoji osvity. Osvita.ua. URL: https://osvita.ua/school/lessons_summary/administration/34011/ (date of issue 02.06.2020).

19. Proghrama rozvytku profesijnoji kompetentnosti pedaghogha. Instytut pisljadyplomnoji osvity Kyjivsjkogho universytetu imeni Borysa Ghrinchenka. URL: http:/ / ippo.kubg.edu.ua/content/17217 (date of issue 02.06.2020).

20. Rozvytok profesijnoji kompetentnosti pedaghogha: korporatyvne navchannja $\mathrm{j}$ avtorsjka proghrama. Sumsjkyj oblasnyj instytut pisljadyplomnoji pedaghoghichnoji osvity. URL: http:/ / www.soippo.edu.ua/index.php/navchalna-robota/3137-23-rozvitok-profesijnojikompetentnosti-pedagoga-korporativne-navchannya-j-avtorska-programa (date of issue 02.06.2020).

21. School of Education. Thompson Rivers University. URL: https://www.tru.ca/edsw/schoolsand-departments/education.html (date of issue 02.06.2020).

22. School of Education. University of Northern British Columbia. URL: https://www.unbc.ca/education/bachelor-of-education (date of issue 02.06.2020).

23. Sydorenko, V. V. (2017). Rozvytok profesijnoji kompetentnosti suchasnogho pedaghogha $\mathrm{V}$ umovakh vidkrytoji osvity: klasternyj analiz. Profesijna kompetentnistj pedaghogha v umovakh onovlenoo zmistu osvity ta vymogho rynku praci: III reghionaljna naukovo-praktychna konferencija. Vinnycja. Vinnycjka misjka drukarnja, 8-17.

24. Tait, M. (2008). Resilience as a Contributor to Novice Teacher Success, Commitment, and Retention. Teacher Education Quarterly, 35 (4), 57-75.

25. Teacher Education. Simon University. URL http:/ / www.sfu.ca/education/teachersed.html (date of issue 02.06.2020).

26. Teacher Education. University of Victoria. URL: https://www.uvic.ca/education/areasstudy/teacher-ed/index.php (date of issue 02.06.2020).

27. Vovchuk, I. O. (2015). Rozvytok profesijno kompetentnosti vchytelja. Tavrijsjkyj visnyk osvity, 3 (51), 54-59.

28. Wawan, W. (2016). The Relationship between of Teacher Competence, Emotional Intelligence and Teacher Performance Madrasah Tsanawiyah at District of Serang Banten. Higher Education Studies, 6(1), 128-135.

29. Zakon Ukrajiny «Pro vyshhu osvitu» vid 01.07.2014 № 1556-VII. Data onovlennja: 18.03.2020. URL: https:/ / zakon.rada.gov.ua/laws/show/1556-18 (date of issue 02.06.2020).

30. Zhuravlova, L., Sheremet, M., Dmytriieva, I., Suprun, D. (2020). State of formation of motivation as one of the structural-functional components of speech development of primary schoolchildren with dysgraphia. International Journal of Psychosocial Rehabilitation, 24 (08), 8985-8999. URL: https://doi.org/10.37200/IJPR/V24I8/PR280893 (date of issue 02.06.2020). 